\title{
Characterization of Bacteriocin Produced by Bacillus subtilis 11A Isolated from the Gastrointestinal Tract of Indonesian Native Chicken (Gallus domesticus)
}

\author{
V A Cahya ${ }^{1}, \mathrm{C} \mathrm{Hanim}^{2, *}$ and L M Yusiati ${ }^{2}$ \\ ${ }^{1}$ Master Program in Faculty of Animal Science, Universitas Gadjah Mada. Fauna Street No. 3, Sleman, Yogyakarta \\ 55281, Indonesia \\ ${ }^{2}$ Department of Animal Nutrition, Faculty of Animal Science, Universitas Gadjah Mada. Fauna Street No. 3, Sleman, \\ Yogyakarta 55281, Indonesia \\ *Corresponding author. Email: c.hanim@ugm.ac.id
}

\begin{abstract}
The purpose of this study was to characterize bacteriocins produced by Bacillus subtilis 11A isolated from Indonesian native chicken's ileum. Characterization of bacteriocins included antimicrobial activity, the stability to temperature, $\mathrm{pH}$, and storage time. Antimicrobial activity was tested against Escherichia coli FNCC 0091, Salmonella typhimurium FNCC 0134, and Staphylococcus aureus FNCC 0143. Stability to temperature was tested to 4, 30, 70, $80,90,100^{\circ} \mathrm{C}$ for an hour and $121^{\circ} \mathrm{C}$ for $15 \mathrm{~min}$. Stability to $\mathrm{pH}$ was tested to $\mathrm{pH} 2,3,4,5,6,7,8,9,10,11$, and 12 for an hour. Stability to storage was tested for $7,14,21$, and 28 days at refrigerator $\left(4^{\circ} \mathrm{C}\right)$ and room temperature $\left(30^{\circ} \mathrm{C}\right)$. The result showed that bacteriocins produced by Bacillus subtilis $11 \mathrm{~A}$ were more effective against pathogens Gram-negative (Escherichia coli and Salmonella typhimurium) than Gram-positive (Staphylococcus aureus) $(\mathrm{P}<0.05)$. The bacteriocins produced by Bacillus subtilis $11 \mathrm{~A}$ were heat until $90^{\circ} \mathrm{C}$, stable at $\mathrm{pH} 6-10$ and stored at refrigerator up to 28 days $(\mathrm{P}<0.05)$. This study suggested that this bacteriocins might become potential candidate for use as biodegradable natural fed and alternative antimicrobial agents to solve the increasing trends of problems of antibiotic resistance.
\end{abstract}

Keywords: Antimicrobial activity, Bacillus subtilis, Bacteriocin, Gallus domesticus, Stability.

\section{INTRODUCTION}

Antibiotics in the field of animal health are used as prevention and treatment of diseases, as well as growthpromoting agents (AGPs) in chicken feed. Antibiotics added to the feed can improve feed efficiency and growth in chickens. The residues of amoxicillin as much as $16.92-152.62 \mu \mathrm{g} / \mathrm{kg}$ in liver and $45.38-60.55 \mu \mathrm{g} / \mathrm{kg}$ in breast meat in broiler chickens and layer chicken in Bangladesh [1]. In 2006, the European Union banned antibiotics as AGP in livestock production, but Indonesia applied these rules was in early 2018. Among alternatives to antibiotics are competitive exclusion products, probiotics, prebiotics, organic acids, plant extracts, and essential oils, feed enzymes, bacteriophages, and hen egg antibodies [2]. Probiotic is 'a live microbial feed supplement which beneficially affects the host animal by improving its intestinal balance' [3]. By inhibiting pathogenic microorganisms in the gastrointestinal tract, probiotics should produce antimicrobial substances such as organic acids, diacetyl, hydrogen peroxide, and bacteriocins [4]. One of the known bacteria which produce bacteriocins genus Bacillus. Bacteriocins are ribosomally synthesized peptides or proteins with antimicrobial properties. Bacteriocins produced by Bacillus have broad-spectrum against Gram-positive and Gramnegative bacteria and could potentially be useful in the food and feed industries as natural preservatives for livestock [5]. Bacteriocins produced by Bacillus have an intense activity of inhibition against the growth of many pathogens such as Staphylococcus aureus, Escherichia coli, Salmonella typhimurium, Listeria monocytogenes, Pasteurella haemolytica 
and Clostridium perfringens [6-9]. This study described the isolation of bacteriocins from the Bacillus subtilis $11 \mathrm{~A}$ isolated from the gastrointestinal tract of Indonesian native chickens. It characterized the

bacteriocins produced by Bacillus subtilis $11 \mathrm{~A}$, which were evaluated by $\mathrm{pH}$ tolerance assay, temperature tolerance assay, and time of storage assay.

\section{MATERIAL AND METHODS}

\subsection{Material}

The tools used in this study were a set of tools to grow the bacteria, Bacillus subtilis 11A isolated from native chicken, three pathogen bacteria (Escherichia coli, Salmonella typhimurium and Staphylococcus aureus), spectrophotometer (Genesys 20 ${ }^{\mathrm{TM}}$ ), centrifuge type 5810R (Eppendorf®), vortex mixer model VM$1000,1.5 \mathrm{~mL}$ safe lock tube, laminar airflow, autoclave, calipers, and analytic scale.

\subsection{Methods}

\subsubsection{Bacterial strains and culture condition.}

Bacillus subtilis 11A was isolated from the native chicken intestines (ileum) and maintained at $-20^{\circ} \mathrm{C}$ in nutrient broth (NB) no. 2 (Oxoid, UK) containing 20\% glycerol (v/v). Indicator organism (Escherichia coli FNCC 0091, Salmonella typhimurium FNCC 0134 and Staphylococcus aureus FNCC 0143) were obtained from Food and Nutrition Culture Collection (FNCC) Universitas Gadjah Mada. Rejuvenation of all bacteria by inoculating an ose of bacteria to $10 \mathrm{~mL} \mathrm{NB}$ media (Oxoid, UK) then incubated at $37^{\circ} \mathrm{C}$ for 24 hours.

\subsubsection{Preparation of cell-free supernatants $(C F S)$.}

Bacteriocins extraction to obtain CFS refers to Sharma et al. [10]. Bacillus subtilis 11A was grown using Luria Bertani media (Oxoid, UK) under conditions $\mathrm{pH} 6.5$ and temperature $39^{\circ} \mathrm{C}$ for 72 hours. Then, cell culture was centrifuged at $10,000 \mathrm{~g}$ for 15 min at $4^{\circ} \mathrm{C}$, then CFS was filtered using a sterile 0.22 $\mu \mathrm{m}$ pore size membrane filters.

\subsubsection{Partial purification of bacteriocins.}

The crude bacteriocins were precipitated using $70 \%$ ammonium sulfate[10], and the obtained pellet was dissolved in $10 \mathrm{mM}$ phosphate buffer saline (PBS), $\mathrm{pH}$ 7.0. The salt was removed using a $12 \mathrm{kDa}$ ultra membrane filter overnight and washed once then harvested - the fraction containing bacteriocins will not pass through the filter.

\subsubsection{Bacteriocins activity assay.}

The antimicrobial activity assay using a welldiffused method refers to Balouiri et al. [11]. With modification in well diameter $(5 \mathrm{~mm})$. A total of $50 \mu \mathrm{L}$ indicator organisms (Escherichia coli, Salmonella typhimurium, and Staphylococcus aureus) dripped on to solid trypticase soy agar (TSA) media then swabbed evenly using a sterile cotton swab, and then, $5 \mathrm{~mm}$ well was made using a cork borer. Each well was dripped as much as $50 \mu \mathrm{L}$ of bacteriocins. Then plates were incubated at $37^{\circ} \mathrm{C}$ for 24 hours. The presence of a clear zone around the well showed the bacteriocins activity of Bacillus subtilis 11A against indicator organisms. Then, clear zone diameter was measured by calipers and converted to an arbitrary unit (AU/ml) [12].

\subsubsection{Effects of heat to bacteriocins stability.}

The bacteriocins were exposed to various temperatures $\left(4,30,70,80,90,100^{\circ} \mathrm{C}\right)$ for $60 \mathrm{~min}$ and autoclaved at $121^{\circ} \mathrm{C}$ for $15 \mathrm{~min}$ to analyze its thermal stability. Then, the bacteriocins' antimicrobial activity were tested.

\subsubsection{Effects of $p H$ to bacteriocins stability.}

Bacteriocins' $\mathrm{pH}$ was adjusted to various $\mathrm{pH}(2-12)$ for $60 \mathrm{~min}$ to examine the effect of $\mathrm{pH}$ on bacteriocins' stability, followed by neutralization of the bacteriocins. Then, the bacteriocins antimicrobial activity were tested.

\subsubsection{Effects of storage time to bacteriocins stability.}

The stability of bacteriocins was checked at a regular interval $(7,14,21$, and 28 days $)$ at room $\left(30^{\circ} \mathrm{C}\right)$ and refrigerator $\left(4^{\circ} \mathrm{C}\right)$ temperature. Then, the bacteriocins antimicrobial activity were tested.

\section{RESULT AND DISCUSSION}

\subsection{Effects of heat to bacteriocins stability}

The results of the statistical analysis showed that heat treatment up to $100^{\circ} \mathrm{C}$ showed the results were not significantly different to the activity of bacteriocins on pathogenic Gram-negative (Escherichia coli and Salmonella typhimurium) $\quad(\mathrm{P}>0.05)$, instead showed real different results on pathogenic Grampositive (Staphylococcus aureus) $(\mathrm{P}<0.05)$. Bacteriocins produced by Bacillus subtilis $11 \mathrm{~A}$ were stable up to a temperature treatment of $90^{\circ} \mathrm{C}$ because it could retain its activity against Staphylococcus aureus, Salmonella typhimurium, and Escherichia coli, respectively up to 60,80 and $83 \%$. Bacteriocins produced by Bacillus subtilis $11 \mathrm{~A}$ stops its activity when given the autoclave treatment. Thus, the bacteriocins produced by Bacillus bacteria were stable for heat treatment [13]. The mechanism of bacteriocins stability to heat was associated with its molecular structure, which was simple peptides without tertiary structures [14].

The bacteriocins produced by Bacillus bacteria were stable to heat treatment up to $80^{\circ} \mathrm{C}$ [15]. Entomocin 9 and 110 produced by Bacillus thuringensis subsp. 
entomocidus HD110 could maintain its activity up to $72 \%$ and $53 \%$ after autoclaved [16]. The bacteriocins treatment gave effect on the decreased activity of bacteriocins due to denaturation. Denaturation caused a

Table 1. The effect of heat to bacteriocins stability produced by Bacillus subtilis 11A

\begin{tabular}{cccc}
\hline Temperature $\left({ }^{\circ} \mathrm{C}\right)$ & Staphylococcus aureus & Salmonella typhimurium $^{\mathrm{ns}}$ & Escherichia coli $^{\mathrm{ns}}$ \\
\hline 4 & $3644.96 \pm 189.40^{\mathrm{b}}$ & $3940.49 \pm 417.03$ & $4040.02 \pm 189.42$ \\
30 & $3336.35 \pm 345.58^{\mathrm{b}}$ & $3451.22 \pm 060.15$ & $3696.54 \pm 056.86$ \\
70 & $2234.11 \pm 084.24^{\mathrm{a}}$ & $3237.44 \pm 238.65$ & $3719.48 \pm 467.18$ \\
80 & $2249.44 \pm 189.99^{\mathrm{a}}$ & $3136.28 \pm 512.77$ & $3683.48 \pm 200.26$ \\
90 & $2168.64 \pm 187.08^{\mathrm{a}}$ & $3164.75 \pm 433.29$ & $3375.81 \pm 541.20$ \\
100 & $2087.10 \pm 060.16^{\mathrm{a}}$ & $3046.43 \pm 000.00$ & $3014.66 \pm 536.49$ \\
121 & - & - & - \\
\hline
\end{tabular}

a,b: Different superscripts in the same column show significant differences $(\mathrm{P}<0.05)$

ns: non-significant $(\mathrm{P}>0.05)$

Table 2. The effect of $\mathrm{pH}$ to bacteriocin stability produced by Bacillus subtilis $11 \mathrm{~A}$

\begin{tabular}{rccc}
\hline $\mathrm{pH}$ & Staphylococcus aureus & Salmonella typhimurium & Escherichia coli \\
\hline 2 & $587.75 \pm 049.61^{\mathrm{a}}$ & $682.11 \pm 105.53^{\mathrm{a}}$ & $1385.00 \pm 156.16^{\mathrm{a}}$ \\
3 & $1647.97 \pm 035.79^{\mathrm{c}}$ & $995.48 \pm 078.62^{\mathrm{b}}$ & $1554.09 \pm 081.21^{\mathrm{a}}$ \\
4 & $1881.75 \pm 108.31^{\mathrm{d}}$ & $1295.72 \pm 099.90^{\mathrm{c}}$ & $1649.54 \pm 143.19^{\mathrm{a}}$ \\
5 & $2073.97 \pm 060.23^{\mathrm{e}}$ & $1793.88 \pm 063.90^{\mathrm{d}}$ & $2371.85 \pm 133.07^{\mathrm{b}}$ \\
6 & $2303.13 \pm 147.52^{\mathrm{f}}$ & $3062.18 \pm 071.26^{\mathrm{g}}$ & $3253.93 \pm 263.88^{\mathrm{d}}$ \\
7 & $2818.09 \pm 044.90^{\mathrm{g}}$ & $3429.51 \pm 168.59^{\mathrm{h}}$ & $4040.02 \pm 189.42^{\mathrm{e}}$ \\
8 & $2275.50 \pm 132.39^{\mathrm{f}}$ & $3015.97 \pm 096.01^{\mathrm{g}}$ & $3465.19 \pm 316.07^{\mathrm{d}}$ \\
9 & $2034.56 \pm 022.57^{\mathrm{e}}$ & $2470.50 \pm 169.56^{\mathrm{f}}$ & $2895.49 \pm 211.74^{\mathrm{c}}$ \\
10 & $1820.15 \pm 153.96^{\mathrm{d}}$ & $2193.44 \pm 061.66^{\mathrm{e}}$ & $2572.49 \pm 265.32^{\mathrm{bc}}$ \\
11 & $832.67 \pm 031.90^{\mathrm{b}}$ & $927.18 \pm 060.20^{\mathrm{b}}$ & $1342.29 \pm 197.29^{\mathrm{a}}$ \\
12 & - & - & - \\
\hline
\end{tabular}

a,b,c,d,e,f,g,h: Different superscripts in the same column show significant differences $(\mathrm{P}<0.05)$

produced by Bacillus subtilis GAS101 were stable up to a temperature of $100^{\circ} \mathrm{C}$ for 60 minutes and $121^{\circ} \mathrm{C}$ for 20 minutes without losing its antimicrobial activity [10]. Bacteriocins produced by Bacillus subtilis 14B were heat stable up to $100^{\circ} \mathrm{C}$ for 120 minutes [17].

\subsection{Effects of $\mathrm{pH}$ to bacteriocin stability}

The results of the statistical analysis showed that there was significantly different on bacteriocins activity affected by the $\mathrm{pH}$ of bacteriocins produced by Bacillus subtilis 11A $(\mathrm{P}<0.05)$. The best $\mathrm{pH}$ treatment was 7 . Bacteriocins produced by Bacillus subtilis 11A were stable in acidic conditions of $\mathrm{pH} \quad 6 \quad(82 \%$ against Staphylococcus aureus, $89 \%$ against Salmonella typhimurium, $81 \%$ against Escherichia coli). The bacteriocins were also stable in alkaline conditions up to $\mathrm{pH} 10$ (65\% against Staphylococcus aureus, 64\% against Salmonella typhimurium, $\quad 72 \%$ against Escherichia coli). Compared to the bacteriocins produced by Bacillus bacteria, they were effective in conditions of $\mathrm{pH} \mathrm{6-7} \mathrm{and} \mathrm{decreasing} \mathrm{its} \mathrm{activity} \mathrm{at} \mathrm{pH} 4$ $[15,18]$. The bacteriocins produced by Bacillus bacteria worked effectively in a $\mathrm{pH}$-neutral range [13]. It is different from bacteriocins produced by bacteria type of Lactobacillus, which is stable at acidic conditions (pH 2-6) [19-21]. The higher and the lower the $\mathrm{pH}$ in change in the structure of the constituent, thereby lowering its biological function [22].

\subsection{Effects of storage time to bacteriocin stability}

The results of the statistical analysis showed that there was a significant difference in bacteriocins activity which affected by storage time at room temperature $(\mathrm{P}<0.05)$. Bacteriocins in the room temperature storage survived for 14 days. The 7-days storage bacteriocins had a high condition of antimicrobial activity. By the 21-days storage, bacteriocins had been inactive. There was a decreased activity of $13 \%$ (Staphylococcus aureus), 23\% (Salmonella typhimurium), and 28\% (Escherichia coli) $(\mathrm{P}<0.05)$ on the $14^{\text {th }}$ day since the $7^{\text {th }}$ day.

The results of the statistical analysis showed that there was no significant difference in bacteriocins activity affected by storage time at the refrigerator for 28 days $(\mathrm{P}>0.05)$. The activity of bacteriocins still showed the optimum activity after its storage for 28 days. The result indicated that the bacteriocins produced by Bacillus subtilis $11 \mathrm{~A}$ was stable in 28 days storage in the refrigerator. The previous study showed that bacteriocins at a temperature of $4^{\circ} \mathrm{C}$ were able to 
survive for 20 days, and its activity significantly decreased when stored at temperature $37^{\circ} \mathrm{C}$ on the $5^{\text {th }}$
Mada for financial support. The authors also gratefully acknowledge to Department of Feed and

Table 3. The effect of storage time at room temperature to bacteriocin stability produced by Bacillus subtilis $11 \mathrm{~A}$

\begin{tabular}{cccc}
\hline Storage time (days) & Staphylococcus aureus & Salmonella typhimurium & Escherichia coli \\
\hline 7 & $2412.83 \pm 063.99^{\mathrm{b}}$ & $2820.19 \pm 204.74^{\mathrm{b}}$ & $3141.26 \pm 164.24^{\mathrm{b}}$ \\
14 & $2103.80 \pm 237.41^{\mathrm{a}}$ & $2180.10 \pm 069.89^{\mathrm{a}}$ & $2261.53 \pm 107.47^{\mathrm{a}}$ \\
21 & - & - & - \\
\hline a,b: Different superscripts in the same column show significant differences $(\mathrm{P}<0.05)$
\end{tabular}

Table 4. The effect of storage time at refrigerator temperature to bacteriocin stability produced by Bacillus subtilis $11 \mathrm{~A}$

\begin{tabular}{cccc}
\hline Storage time (days) & Staphylococcus aureus $^{\mathrm{ns}}$ & Salmonella typhimurium $^{\mathrm{ns}}$ & Escherichia coli $^{\mathrm{ns}}$ \\
\hline 7 & $3347.71 \pm 122.15$ & $3938.82 \pm 356.77$ & $3937.87 \pm 328.16$ \\
14 & $3000.85 \pm 122.66$ & $3627.96 \pm 175.12$ & $3696.62 \pm 254.21$ \\
21 & $3113.83 \pm 328.28$ & $3627.43 \pm 133.45$ & $3746.49 \pm 207.48$ \\
\hline
\end{tabular}

ns: non-significant $(\mathrm{P}>0.05)$

day [20]. The bacteriocins produced by Bacillus megaterium 22 could survive up to 90 days at $4^{\circ} \mathrm{C}$ [9]. The best way to keep bacteriocin was at low temperatures $\left(\leq 4^{\circ} \mathrm{C}\right)$ because it could maintain its stability up to 6 weeks, while bacteriocins in $37^{\circ} \mathrm{C}$ storage only last up to 4 weeks [23].

Bacteriocin's peptides were one of the nutrients that were needed by the microorganisms to grow. When bacteriocins stored at room temperature, many microorganisms may grow to utilize this peptide as nutrients source so that bacteriocins would be easily damaged. Therefore, its activity decreased due to the growth of microorganisms. Low temperatures storage inhibits the growth of microorganisms that use these peptides. Microorganisms are generally dormant at low temperatures $\left(\leq 4^{\circ} \mathrm{C}\right)$, thus bacteriocins low-temperature storage could last longer, and the decrease of its activity was lower than storage at room temperature [24,25].

\section{CONCLUSION}

Based on the results of the research obtained, it is concluded that the bacteriocins produced by Bacillus subtilis $11 \mathrm{~A}$ was heat-stable until $90^{\circ} \mathrm{C}, \mathrm{pH} 6-10$, and refrigerator storage up to 28 days.

\section{ACKNOWLEDGMENTS}

The authors would like to thank Rekognisi Tugas Akhir (RTA) program from Universitas Gadjah
Animal Nutrition, Faculty of Animal Science, Universitas Gadjah Mada, Yogyakarta.

\section{REFERENCES}

[1] Sattar S, Hassan M M, Islam S K M A, Alam M, Faruk M S Al, Chowdhury S and Saifuddin A K M 2014 Antibiotic residues in broiler and layer meat in Chittagong district of Bangladesh Vet. World 7 738-43

[2] Dahiya J P, Wilkie D C, Van Kessel A G and Drew M D 2006 Potential strategies for controlling necrotic enteritis in broiler chickens in post-antibiotic era Anim. Feed Sci. Technol. $12960-88$

[3] Fuller R 1989 Probiotics in man and animals $J$. Appl. Bacteriol. 66 365-78

[4] Cleveland J, Montville T J, Nes I F and Chikindas M L 2001 Bacteriocins: safe, natural antimicrobials for food preservation Int. J. Food Microbiol. 290

[5] Abriouel H, Franz C M A P, Omar N Ben and Galvez A 2011 Diversity and applications of Bacillus bacteriocins FEMS Microbiol. Rev. 35 201-32

[6] Lisboa M P, Bonatto D, Bizani D, Henriques J A $\mathrm{P}$ and Brandelli A 2006 Characterization of a bacteriocin-like substance produced by Bacillus 
amyloliquefaciens isolated from the Brazilian Atlantic forest Int. Microbiol. 9 111-8

[7] Diaz D 2007 Effect of Bacillus amyloliquefaciens CECT-5940 spores on broiler performance and digestibility Poult. Ind. 1-5

[8] Xie J, Zhang R, Shang C and Guo Y 2009 Isolation and characterization of a bacteriocin produced by an isolated Bacillus subtilis LFB112 that exhibits antimicrobial activity against domestic animal pathogens African $J$. Biotechnol. 8 5611-9

[9] Khalil R, Djadouni F, Elbahloul Y and Omar S 2009 The influence of cultural and physical conditions on the antimicrobial activity of bacteriocin produced by a newly isolated Bacillus megaterium 22 strain African J. Food Sci. 3 11-22

[10] Sharma G, Dang S, Gupta S and Gabrani R 2018 Antibacterial activity, cytotoxicity, and the mechanism of action of bacteriocin from Bacillus subtilis GAS101 Med. Princ. Pract. 27 186-92

[11] Balouiri M, Sadiki M and Ibnsouda S K 2016 Methods for in vitro evaluating antimicrobial activity: A review J. Pharm. Anal. 6 71-9

[12] Usmiati S and Marwati T 2007 Seleksi dan optimasi proses produksi bakteriosin dari Lactobacillus sp. Indones. J. Agric. Postharvest Res. 4 27-37

[13] Maina J W, Mathara J M, Kikuvi G M and Ouma S O 2017 Bacteriocins: Limiting factors to optimum activity J. Food Secur. 5 19-25

[14] Usmiati S and Rahayu W P 2011 Inhibitory Activity of bacteriocin extract from Lactobacillus sp. strain SCG 12231223 388-97

[15] Tagg J R, Dajani A S and Wannamaker L W 1976 Bacteriocins of gram-positive bacteria. Bacteriol. Rev. $40722-56$

[16] Cherif A, Rezgui W, Raddadi N, Daffonchio D and Boudabous A 2008 Characterization and partial purification of entomocin 110, a newly identified bacteriocin from Bacillus thuringiensis subsp. Entomocidus HD110 Microbiol. Res. 163 684-92

[17] Hammami I, Rhouma A, Jaouadi B, Rebai A and Nesme X 2009 Optimization and biochemical characterization of a bacteriocin from a newly isolated Bacillus subtilis strain 14B for biocontrol of Agrobacterium spp. strains Lett. Appl. Microbiol. 48 253-60

[18] Ennahar S, Sashihara T, Sonomoto K and Ishizaki A 2000 Class IIa bacteriocins: Biosynthesis, structure and activity FEMS Microbiol. Rev. 24
$85-106$

[19] Ogunbanwo, S T, Sanni A I and Onilude A A 2003 Characterization of bacteriocin produced by Lactobacillus plantarum F1 and Lactobacillus brevis OG1 African J. Biotechnol. 2 219-27

[20] Sivakumar N, Rajamani and Saif A B 2010 Partial Characterization of bacteriocins produced by Lactobacillus acidophilus and Pediococcus acidilactici Brazilian Arch. Biol. Technol. 53 1177-84

[21] Fatima D 2014 Characterization and determination of the factors affecting antilisterial bacteriocins from Lactobacillus plantarum and Pediococcus pentosaceus isolated from dairy milk products African J. Food Sci. 7 $35-44$

[22] Todorov S D and Dicks L M T 2006 Screening for bacteriocin-producing lactic acid bacteria from boza, a traditional cereal beverage from Bulgaria: Comparison of the bacteriocins Process Biochem. 41 11-9

[23] Sumathi V and Reetha D 2012 Effect of storage time and temperature for maximum bacteriocin production by lactic acid bacteria. Ijpba 3 831-4

[24] Riley M A and Chavan M 2007 Bacteriocins: Ecology and Evolution (Berlin Heidelberg: Springer-Verlag)

[25] Hogg S 2018 Essential Microbiology Second Edition (West Sussex United Kingdom: WileyBlackwell 